\author{
RESEARCHPAPER
}

\title{
In vitro bioassay to study phytotoxicity affects of Quercus leucotrichophora on some small millets varieties
}

\author{
BHUPENDRA SINGH, UDAY BHANU PRATAP, YOGENDRA SINGH GUSAIN AND C.S. DHANAI
}

Department of Forestry, College of Forestry, VCSG Uttarakhand University of Horticulture and Forestry, RANICHAURI (UTTARAKHAND) INDIA

Email : butola_bs@yahoo.com

Article Info :Received : 28.12.2015; Accepted : 11.02.2016

The present study was conducted for the evolution of phytoxiticy of leaves and bark extracts of Quercus leucotrichophora on seed germination and radical and plume growth of different small millets verities. On average leaves extracts were more toxic to germination and growth of test crops as compared to barks extracts. Lower concentration of leaves and barks extracts stimulated the germination and radicle and plumule growth of the test crops as compared with the control. These results also indicated that radicle growth of test crops were more inhibited as compared to the plumule growth in all the text crops, irrespective of concentration. On an average, germination of all the small millets varieties resistance against the leaves and barks extracts. While seedling growth of Echinochloa frumentacea and Amaranthus caudatus showed some resistance and Triticum aestivum and Eleusine coracana were sensitive crops.

Key words : Allelopathy, Germination, Radicle, Plumule, Small millets

How to cite this paper: Singh, Bhupendra, Pratap, Uday Bhanu, Gusain, Yogendra Singh and Dhanai, C.S. (2016). In vitro bioassay to study phytotoxicity affects of Quercus leucotrichophora on some small millets varieties. Asian J. Bio. Sci., 11 (1) : 136-140 [Special Issue of AFBSAH-2016]. 